COSTING:Journal of Economic, Business and Accounting

Volume 4 Nomor 2, Juni 2021

e-ISSN : 2597-5234

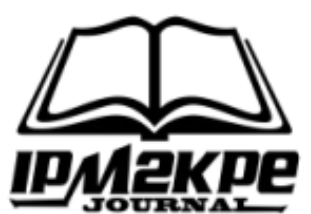

\title{
PENGARUH WORD OF MOUTH DAN KEPERCAYAAN TERHADAP KEPUTUSAN PENGAMBILAN KREDIT USAHA RAKYAT (KUR) BANK BNI UNIT JALAN BARU KABUPATEN KARAWANG
}

\author{
THE INFLUENCE WORD OF MOUTH AND COSTUMER TRUST \\ ON DICISION MAKING KREDIT USAHA RAKYAT(KUR) \\ BANK BRI UNIT JALAN BARU KARAWANG DISTRICT
}

\author{
Ismi Salamah', Ajat Sudrajat ${ }^{2}$ \\ Universitas Singaperbangsa Karawang, Indonesia ${ }^{1,2}$ \\ ismisalamah95@gmail.com ${ }^{1}$
}

\begin{abstract}
This study aims to determine the description of the variable word of mouth, customer trust, and decision making of people's business credit (KUR) at Bank BRI Unit Jalan Baru, Karawang Regency. In addition, this study aims to determine the effect partially and simultaneously between word of mouth and customer trust on the decision to make people's business credit (KUR) at Bank BRI Unit Jalan Baru, Karawang Regency. The type of data used in this research is quantitative data. This research was conducted on customers of the People's Business Credit (KUR) BRI Bank Unit Jalan Baru, Karawang Regency. The analysis model used in this research is the path analysis model. Based on the results of descriptive analysis, it shows that the word of mouth variable gets an average score of 474 on the agreeing criteria, then the customer trust variable gets an average score of 435.5 in the agreeing criteria, while the people's business credit decision-making variable (KUR) gets an average -The average score of 494.5 is on the agreed criteria. Based on the results of hypothesis testing, it shows that there is a partial and simultaneous influence on word of mouth and customer trust on the decision of making people's business credit (KUR) at Bank BRI Unit Jalan Kabupaten Karawang.
\end{abstract}

Keyword : Word of mouth, Costumer Trust, Dicision Making Kredit

\footnotetext{
ABSTRAK

Penelitian ini bertujuan untuk mengetahui gambaran variabel word of mouth, kepercayaan nasabah, dan keputusan pengambilan kredit usaha rakyat (KUR) Bank BRI Unit Jalan Baru Kabupaten Karawang. Selain itu penelitian ini bertujuan untuk mengetahui pengaruh secara parsial dan simultan antara word of mouth dan kepercayaan nasabah terhadap keputusan pengambilan kredit usaha rakyat (KUR) Bank BRI Unit Jalan Baru Kabupaten Karawang. Jenis data yang digunakan dalam penelitian ini adalah data kuantitatif. Penelitian ini dilakukan pada nasabah Kredit Usaha Rakyat (KUR) Bank BRI Unit Jalan Baru Kabupaten Karawang. Model analisis yang digunakan dalam penelitian ini adalah model analisis jalur. Berdasarkan hasil analisis deskriptif menunjukan bahwa variabel word of mouth memperoleh rata-rata skor sebesar 474 pada kriteria setuju, kemudia variabel kepercayaan nasabah memperoleh rata-rata skor 435,5 berada pada kriteria setuju,
} 
sedangkan variabel keputusan pengambilan kredit usaha rakyat (KUR) memperoleh ratarata skor 494,5 berada pada kriteria setuju. Berdasarkan hasil pengujian hipotesis menunjukan bahwa terdapat pengaruh secara parsial dan simultan word of mouth dan kepercayaan nasabah terhadap keputusan pengambilan kredit usaha rakyat (KUR) Bank BRI Unit Jalan Kabupaten Karawang.

Kata Kunci : Word of mouth, Kepercayaan Nasabah, Keputusan Pengambilan Kredit

\section{PENDAHULUAN}

Pertumbuhan ekonomi adalah suatu proses kenaikan pendapatan total dan pendapatan perkapita dengan memperhitungkan adanya pertambahan penduduk dan disertai dengan perubahan fundamental dalam struktur ekonomi suatu negara.

Perkembangan perekonomian dewasa ini menuntut penyedia jasa keuangan seperti lembaga keuangan perbankan dan lembaga keuangan lainnya agar selalu berinovasi dan mengembangkan produk jasa keuangan yang sediakan.

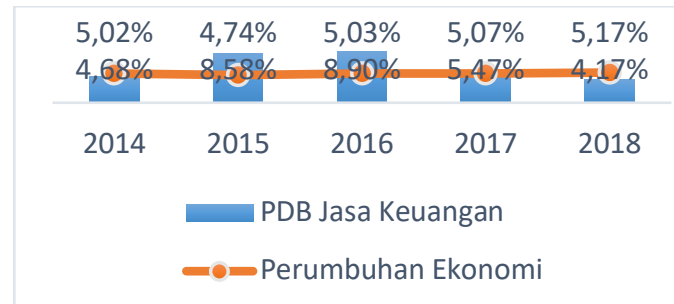

Sumber; Laporan Perekonomian Indonesia (2019)

Gambar 1 Penerimaan PDB Jasa Keuangan dan Pertumbuhan Ekonomi

Pada gambar 1 perkembangan industri jasa keuangan terhadap Produk Domestik Bruto mengalami penurunan pada tahun 2018 lebih rendah dari 2017, Sepanjang tahun 2018, kondisi perekonomian nasional terpantau sehat dan stabilyang tercermin di antaranya dari ekonomi nasional yang tumbuh sekitar 5,17\% Sementara itu sektor jasa keuangan juga tercatat stabil dan sehat, meski mengalami penurunan terhadap PDB sebesar $1,3 \%$ year on year (yoy).

Secara umum lembaga keuangan dapat di kelompokkan dalam 2 bentuk yaitu bank dan bukan bank, dimana perbedaan utama antara kedua lembaga tersebut adalah pada penghimpunan dana. dalam penghimpunan dana secara tegas disebutkan bahwa bank bisa menghimpun dana baik secara pribadi juga tidak langsung dari masyarakat sedangkan lembaga keuangan bukan bank hanya bisa menghimpun dana secara tidak langsung berasal masyarakat (Ana dan Viola, 2019).

Potensi pasar yang sangat besar saat ini mengakibatkan Bank Rakyat Indonesia (BRI) adalah salah satu bank milik pemerintah yang terbesar di Indonesia. Bank Rakyat Indonesia (BRI) didirikan di Purwokerto, Jawa Tengah oleh Raden Bei Aria Wirjaatmadja tanggal 16 Desember 1895. Bank bri terus berupaya meningkatkan kualitas layanan dan memberikan solusi-solusi terbaik dalam memenuhi kebutuhan nasabah. Bank BRI menerbitkan berbagai produk dan aktivitas baru, memperkaya bussiness model dan menyempurnakan bussiness process, baik dalam rangka mempertahankan existing customer maupun menyasar new customer. Tidak saja terbatas dalam konteks sebagai lembaga intermediasi tetapi juga penyedia layanan jasa sistem pembayaran yang handal, terpercaya dan efisien (Baroroh, 2012). 
Sesuai dengan fungsi umum bank sebagai lembaga keuangan masyarakat yang bertujuan untuk menyalurkan kembali dana yang telah dihimpun ke masyarakat melalui sistem kredit. Saat ini masyarakat sudah lebih cerdas dalam menentukan pilihannya untuk memilih produk perbankan sesuai dengan keinginan mereka. Sangat disadari bahwa salah satu yang mempengaruhi daya saing produk kredit adalah perilaku kosumen (nasabah) dalam memilih produk kredit apa yang mereka butuhkan, sedangkan pihak perbankan telah menerapkan strategi pemasaran sesuai dengan kebijakan perbankan itu sendiri, dengan menerapkan strategi pemasaran yang efektif maka perusahaan diharapkan dapat mengetahui apa yang harus dilakukan agar dapat memuaskan kebutuhan dan keinginan nasabah, bahkan sekaligus merubah perilaku konsumen (Jamal, 2014).

Hal ini dapat dilakukan dengan menggunakan iklan di berbagai media cetak, radio, televisi, maupun internet. Iklan melalui media sangat efektif tetapi memerlukan biaya yang relatif tinggi. Ada beberapa alasan yang signifikan faktor pertama the growth of consumer's power yaitu Konsumen memiliki kekuatan yang luar biasa dengan banyaknya media elektronik, media cetak, media internet, dan media bergerak (mobile phone) membuat konsumen mudah mencari semua informasi tentang sebuah produk atau merk. Di sisi lain, konsumen semakin mudah mengutarakan kesalahan, opini dan keluhan kepada masyarakat umum melalui media. Hal ini mengakibatkan pemilik produk atau merk tidak dapat lagi menutupi segala informasi negatif dan tidak dengan mudah mengakali pelanggan. Faktor kedua cultured media yaitu pertumbuhan media baik stasiun televisi nasional atau lokal termasuk juga media cetak seperti majalah dan surat kabar. Banyaknya media membuat pemasar menentukan media yang efektif. Pelanggan juga sulit memilih sumber yang relevan. Inilah yang membuat Word of mouth marketing mengambil alih peranan iklan. Faktor ketiga pressure to marketing account ability yaitu perusahaan meminta pertanggungjawaban bagian pemasaran dalam hal alokasi dan efektivitas anggaran. Ketiga hal tersebut memicu pemasar mencari alternatif kreatif untuk menjalankan program komunikasi pemasaran dengan Word of mouth marketing.

Kekuatan dari Word of mouth terletak pada kredibilitas dan relevansi dari apa yang dibicarakan oleh seseorang. Hal tersebut dikarenakan terdapat studi yang menunjukkan bahwa sumber yang paling dapat dipercaya terhadap informasi suatu produk adalah keluarga dan teman.

Kepercayaan merupakan salah satu pondasi dari bisnis apapun, suatu transaksi bisnis antara dua belah pihak atau lebih akan terjadi apabila masingmasing pihak saling mempercayai. Kepercayaan ini tidak begitu saja dapat diakui oleh pihak lain atau mitra bisnis, melainkan harus dibangun mulai dari awal dan dapat dibuktikan (Wisnu, 2019).

Ketika konsumen mempercayai sebuah perusahaan, mereka akan lebih suka melakukan pembelian ulang dan membagi informasi pribadi yang berharga kepada perusahaan tersebut (Setiawan, et.al, 2020).

Salah satu yang mempengaruhi daya saing produk kredit adalah perilaku kosumen (nasabah) dalam memilih produk kredit apa yang mereka 
butuhkan, sedangkan pihak perbankan telah menerapkan strategi pemasaran sesuai dengan kebijakan perbankan itu sendiri, dengan menerapkan strategi pemasaran yang efektif maka perusahaan diharapkan dapat mengetahui apa yang harus dilakukan agar dapat memuaskan kebutuhan dan keinginan nasabah (Hari dan Raden, 2019).

Berdasarkan uraian diatas peneliti tertarik untuk mengambil judul "Pengaruh Word of mouth dan Kepercayaan terdahap Keputusan Pengambilan Kredit Usaha Rakyat (KUR) Bank BRI Unit Jalan Baru Kabupaten Karawang”.

\section{METODE PENELITIAN}

Metode penelitian pada dasarnya merupakan suatu cara ilmiah untuk mendapatkan data dengan tujuan dan kegunaan tertentu. Metode penelitian adalah cara ilmiah kegiatan penelitian itu didasarkan pada ciri-ciri keilmuan, yaitu rasional, empiris, dan sistematis. maka dari itu peneliti terlebih dahulu akan menentukan metode penelitian yang akan digunakan, dalam penelitian ini menggunakan metode penelitian Kuantitatif dan analisa menggunakan regresi linear berganda dengan SPSS.

\section{HASIL DAN PEMBAHASAN}

Korelasi Word of Mouth dan Kepercayaan Nasabah

Pada pengujian hipotesis korelasi antara word of mouth dan kepercayaan nasabah mempunyai $t_{\text {hitung }}(3.071)>\mathrm{t}_{\text {tabel }}$ $(1,980)$ hal ini menunjukan terdapat hubungan antara Word of mouth terhadap Kepercayaan nasabah Bank BRI Unit Jalan Baru Kabupaten Karawang.
Korelasi antara word of mouth dan kepercayaan nasabah adalah 0,272 dapat disimpulkan bahwa word of mouth dan kepercayaan nasabah termasuk ke dalam kategori hubungan yang rendah karena terdapat pada interval 0,200 0,399 .

Pengaruh Word of mouth terhadap Keputusan Pengambilan Kredit Hasil pengujian hipotesis pengaruh word of mouth terhadap Keputusan Pengambilan Kredit menghasilkan nilai $t_{\text {hitung sebesar } 7.682>}$ $t_{\text {tabel }} 1.980$ dengan sig. $(0,005)<\alpha$ $(0,05)$, menunjukkan terdapat pengaruh Word of mouth Terhadap Keputusan Pengambilan Kredit Usaha Rakyat (KUR) Bank BRI Unit Jalan Baru. besarnya pengaruh variabel Word of mouth $\left(\mathrm{X}_{1}\right)$ terhadap Keputusan pengambilan kredit (Y) sebesar 37,6\%.

Pengaruh Kepercayaan Nasabah terhadap Keputusan Pengambilan Kredit

Hasil pengujian hipotesis pengaruh kepercayaan nasabah terhadap keputusan pengambilan kredit menghasilkan memaparkan nilai thitung sebesar $3.227>t_{\text {tabel }} 1.980$ dengan sig. $(0,005)<\alpha(0,05)$, menunjukkan terdapat pengaruh Kepercayaan Nasabah Terhadap Keputusan Pengambilan Kredit Usaha Rakyat (KUR) Bank BRI Unit Jalan Baru. Besarnya pengaruh Kepercayaan nasabah terhadap Keputusan pengambilan kredit (Y) sebesar $12,5 \%$.

Pengaruh Word of mouth dan Kepercayaan Nasabah terhadap Keputusan Pengambilan Kredit

Terdapat pengaruh Word of
mouth dan Kepercayaan terhadap


Keputusan Pengambilan Kredit Usaha Rakyat (KUR) Bank BRI Unit Jalan Baru Kabupaten Karawang karena bahwa nilai $F_{\text {hitung }}$ sebesar $31.640<\mathrm{F}_{\text {tabel }}$ 3.070 dengan sig. $(0,001)<\alpha(0,05)$. Total pengaruh Word of mouth dan Kepercayaan nasabah terhadap Keputusan pengambilan kredit (Y) yaitu sebesar 50,1 \%. Adapun pengaruh variabel lain di luar model adalah sebesar $1-0,501=0,499$ atau 49,9\%.

\section{PENUTUP}

\section{Kesimpulan}

Dari hasil penelitian dan pembahasan yang telah dijelaskan pada bab sebelumnya, maka dapat disimpulkan sebagai berikut:

1. Word of mouth Kredit Usaha Rakyat (KUR) Bank BRI Unit Jalan Baru atas tanggapan responden diperoleh skor sebesar 2,853 dengan rata-rata skor sebesar 474 berada pada kriteria setuju. Artinya word of mouth Kredit Usaha Rakyat (KUR) Bank BRI Unit Jalan Baru sudah baik. Terdapat nilai tertinggi Indikator dengan jumlah skor tertinggi adalah kualitas informasi dengan skor sebesar 495. Hal ini menunjukkan bahwa word of mouth Kredit Usaha Rakyat (KUR) Bank BRI Unit Jalan Baru sudah baik dengan dilihat bahwa Costumer Service Bank BRI menyampaikan pesan mengenai Kredit Usaha Rakyat (KUR) Bank BRI secara lugas dan jelas sehingga responden dapat mengerti maksud yang disampaikan. Namun, terdapat indikator yang mempunyai skor paling rendah yaitu minat membeli dengan skor sebesar 453. Hal ini disebabkan kurangnya minat responden untuk mengambil Kredit Usaha Rakyat (KUR) Bank BRI setelah mendapat rekomendasi dari orang lain.

2. Kepercayaan Nasabah Kredit Usaha Rakyat (KUR) atas tanggapan responden diperoleh skor sebesar 2,721 dengan rata-rata skor sebesar 453,5 berada pada kriteria setuju. Artinya kepercayaan nasabah Kredit Usaha Rakyat (KUR) Bank BRI Unit Jalan Baru sudah baik. Terdapat Indikator dengan jumlah skor tertinggi adalah keramahan debitur dengan skor sebesar 473. Hal ini menunjukkan bahwa kepercayaan nasabah Kredit Usaha Rakyat (KUR) Bank BRI Unit Jalan Baru sudah baik dengan dilihat bahwa karyawan Bank BRI Unit Jalan Baru ramah terhadap nasabah. Namun, terdapat indikator yang mempunyai skor paling rendah yaitu kesesuaian produk dengan skor sebesar 444, hal ini disebabkan produk Kredit Usaha Rakyat (KUR) Bank BRI kurang sesuai dengan apa yang responden harapkan.

3. Keputusan pengambilan Kredit Usaha Rakyat (KUR) Bank BRI Unit Jalan Baru atas tanggapan responden diperoleh skor sebesar 2,967 dengan rata-rata skor sebesar 494,5 berada pada kriteria setuju. Artinya keputusan Kredit Usaha Rakyat (KUR) Bank BRI Unit Jalan Baru sudah baik. Terdapat Indikator dengan jumlah skor tertinggi adalah kebutuhan produk dengan skor sebesar 505. Hal ini menunjukkan bahwa responden memilih Produk Kredit Usaha Rakyat (KUR) Bank BRI karena sesuai kebutuhan untuk pengembangan bisnis responden sudah baik. Namun, terdapat indikator yang mempunyai skor paling rendah yaitu pemilihan 
produk dengan skor sebesar 486, hal ini menunjukan bahwa responden memilih produk Kredit Usaha Rakyat (KUR) Bank BRI dibanding produk kredit lainnya.

4. Korelasi antara word of mouth dan kepercayaan nasabah adalah 0,272 dapat disimpulkan bahwa word of mouth dan kepercayaan nasabah termasuk ke dalam kategori hubungan yang rendah.

5. Terdapat pengaruh positif dan signifikan word of mouth terhadap Keputusan Pengambilan Kredit. Besarnya pengaruh word of mouth terhadap Keputusan Pengambilan Kredit adalah 37,6\%.

6. Terdapat positif dan signifikan kepercayaan nasabah terhadap Keputusan Pengambilan Kredit Usaha Rakyat (KUR) Bank BRI Unit Jalan Baru. Besarnya Pengaruh kepercayaan nasabah terhadap keputusan pengambilan kredit sebesar $12,5 \%$.

7. Terdapat Pengaruh positif dan signifikan Word of mouth dan Kepercayaan nasabah terhadap Keputusan pengambilan kredit. besarnya pengaruh Word of mouth dan Kepercayaan nasabah terhadap Keputusan pengambilan kredit yaitu sebesar 50,1 \%. Adapun pengaruh variabel lain di luar model adalah sebesar 49,9\%.

\section{Saran}

\section{Saran Bagi Perusahaan}

1. Mengacu pada variabel Word $O f$ Mouth berdasarkan indikator terendah yakni minat membeli sebaiknya Bank BRI Unit Jalan Baru Kabupaten Karawang lebih giat dalam melaksanakan promosi Kredit Usaha Rakyat melalui endoser tokoh publik untuk meningkatkan peran rekomendasi orang lain.

2. Mengacu pada variabel kepercayaan nasabah berdasarkan indikator terendah yakni kesesuaian produk sebaiknya Bank BRI Unit Jalan Baru Kabupaten Karawang menguatkan peran dari Divisi Research \& 140 Development (R\&D) agar tercipta kesesuaian antara produk dan ekspetasi nasabah.

3. Mengacu pada variabel keputusan pengambilan kredit berdasarkan indikator terendah yakni pemilihan produk sebaiknya Bank BRI Unit Jalan Baru menurunkan suku bunga acuan untuk produk Kredit Usaha Rakyat yang sebelumnya $6 \%$ menjadi $5 \%$ dan meningkatkan pelayanan dengan sistem pengajuan peminjaman secara online.

\section{Saran Bagi Nasabah}

Word of mouth dan kepercayaan nasabah Bank BRI memberikan respon bagi keputusan pengambilan kredit usaha rakyat, perusahaan akan terus melakukan yang terbaik bagi para nasabah dan selalu meningkatkan layanan agar nasabah selalu merasa puas.

\section{Saran Bagi Peneliti Selanjutnya}

Penelitian ini hendaknya dijadikan acuan dan penambahan wawasan mengenai penelitian, maka bagi peneliti selanjutnya diharapkan melakukan hal sebagai berikut :

1. Peneliti selanjutnya dapat meneruskan penelitian ini dengan meneliti lebih lanjut dari kesimpulan yang dihasilkan pada peneliti ini.

2. Apabila peneliti selanjutnya tertarik untuk melakukan penelitian lebih lanjut, disarankan meneliti ditempat 
yang berbeda dengan 141 menggunakan sampel yang lebih banyak lagi agar hasilnya lebih beragam.

3. Mampu mengaplikasikan teori berdasarkan hasil yang telah dicapai.

\section{DAFTAR PUSTAKA}

Ana, A., J.,L \& Viola, D.,Y. (2019). Pengaruh Kepercayaan (Trust) menggunakan e-commerce terhadap Keputusan Pengambilan Kredit Usaha Rakyat (KUR) Online. Jurnal Bisnis Darmajaya, $5(1)$

Baroroh, U. (2012). Analisis Sektor Keuagan terhadap Pertumbuhan Ekonomi Regional di wilayah Jawa: Pendekatan Model Levine. Etikomi. 11 (2)

Hari, S., Disemadi \& Raden, A.,E., W. (2019). Eksistensi dan Kebijakan Regulasi Perizinan Lembaga Keuangan Mikro oleh Otoritas Jasa Keuangan. Jurnal Yustisiabel 3(2): 106-17.

Jamal, W. (2014). Peran Lembaga Keuangan Bank dan Lembaga Keuangan Bukan Bank dalam Memberikan Distribusi Keadilan Bagi Masyarakat. MasalahMasalah Hukum, 43(1): 87-97.

Setiawan, O., Simorangkir, E. S., \& Purwati, A. A. (2020). Pengaruh Kualitas Produk, Harga, Relationship Marketing terhadap Keputusan Pembelian Produk di PT Asaba Pekanbaru. Management Studies and Entrepreneurship Journal (MSEJ), 1(1), 64-77.

Wisnu, R., Adhitya. (2019). Analisis Perilaku Nasabah dan Loyalitas Nasabah Terhadap Pengambilan Keputusan Kredit di Koperasi
Simpan Pinjam Baitul Maal Wattamwill (Bmt) Medan Johor. Accumulated Journal, 1(2). 